\title{
STATUS AND DISTRIBUTION OF BATS IN BANGLADESH WITH NOTES ON THEIR ECOLOGY
}

\author{
Mohammad Ali Reza Khan \\ Dubai Zoo, P.O. Box 67, Dubai, United Arab Emirates. \\ (Ex-Associate Professor of Zoology, Dhaka University, Bangladesh) \\ Email:mark1147@emirates.net.ae;MAKHAN@dm.gov.ae
}

\begin{abstract}
Bangladesh supports 31 species of bats including three species of fruit bats. The flying fox is still a common and widely distributed species among the fruit bats whereas the Indian Pipistrelle is the commonest among the smaller insectivorous bats. The largest of the insect bats is the False Vampire that is also quite common and widely distributed in the country. Most bat population are declining because of habitat destruction. An estimated 80 per cent of known roosts of the flying fox have been lost during the past three decades. Bangladesh Wildlife Preservation Act does not protect the bats.
\end{abstract}

\section{Key words}

Bats, Bangladesh, distribution, ecology

\section{Introduction}

Most people in Bangladesh hate bats. Their hatred is based mostly on century-old misconceptions and ignorance about these flying vertebrates. All fruit bats are considered pests of banana, mango, litchi and other commercially important fruits cultivated in the country when their value as pollinator and seed dispersal is totally ignored. Some people believe that certain bats are 'blood suckers' at the same time not knowing that the smallest of the insect bats devour several thousand wingedinsects, many of which are pests of agricultural crops or human parasites. Others believe that bats pass stools 'through the mouth', or that they are a certain type of 'bird'! Then there are tribal and nomadic people who kill and eat flying foxes. Village lads and some people kill bats just for fun. Many flying foxes die by hitting the overhead electric cables laid throughout the length and breadth of the country.

In this context, the present paper is an attempt to summarize information available on the literature about bats and record the author's experience with the group for the past three decades.

Received 20 September 2000

Accepted 17 March 2001
Bangladesh as a deltaic floodplain of recent origin has a variety of habitats suitable for a diverse fauna (Khan 1982, 1985, 1987). As many as 125 species of a mammals have been reported from the country (IUCN Bangladesh, 2000; Khan, 1982, in press). This is inclusive of 31 species of bats (Khan, 1982). Sarker and Sarker (1988) reported only 17 species while IUCN Bangladesh (2000), largely based on the checklist of Khan (1982), listed 29 species of bats from Bangladesh. However, systematic fieldwork has been conducted on this group of mammals excepting a few specimen collections by Ahmed (1975). The scientific and common names in this paper follow Bates and Harrison (1997).

\section{Status of forests in Bangladesh}

Bangladesh has an area of 147,570 $\mathrm{km}^{2}$ and lies between 20 $34^{\prime}$ to $26^{\circ} 38^{\prime} \mathrm{N}$ and $88^{\circ} 91^{\prime}$ to $92^{\circ} 41^{\prime} \mathrm{E}$. Total forested area is said to be about eight per cent of the country when per capita forest is 0.02 ha, one of the lowest forest to population ratios in the world (IUCN Bangladesh, 2000). Major wildlife habitats include severely depleted semi-evergreen forest along the northeastern and southeastern parts of the country bordering the Indian states of Assam, Mizoram, and Tripura. Sal or deciduous forest occur at the centre and north-central parts and the Sundarbans mangrove forest in the southwestern corner of the country. The Sal forest is along the border with the Indian state of Tripura while the Sundarbans border the West Bengal State. The then East Pakistan (from August 1947 up to December 1971 Bangladesh used to be known as East Pakistan, as the eastern province of Pakistan) and present Bangladesh Government's wrong forestry policy of clear-felling of virgin forests and replacing the same with either monoculture of indigenous or alien tree species that is commercially viable has literally wiped out the natural forests from this belt. The same is the case with the Sal forest. However, the condition of Sundarbans is much better than the rest of the forests so far as forestry practice is concerned. Here the government forest department attempted selective logging instead of clear-felling operations. Never-theless with the commissioning of Farakkah Barrage and excessive withdrawal of water from the upper reaches of the River Padma by the upper riparian countries, less freshwater is being 
discharged through the rivers that pass through the Sundarbans. As a result of this there appears a phenomenon of 'top-dying' of the Sundri trees (Heritiera fomes) in the Bangladesh part of the Sundarbans (Nazrul Islam, pers. comm.).

In addition to these types of forest there are nearly 70,000 villages in the country that have village groves suitable for holding certain species of wildlife. Bats use all these habitats as well as manmade structures such as abandoned houses, forts, sparingly used office blocs, places of worship, monuments, mosques, tombs, dilapidated buildings, ruins, disused road and railway bridges and culverts. They also use caves, holes, hollows in trees, crevices, cracks and fissures in rocks, buildings and spaces between junctions of beams, spans in buildings or bridges, ceilings, roofs, rafters, attics, overhead water tanks and abandoned or old wells.

This paper summarizes preliminary information on the status, distribution, and ecological notes on the bat fauna of Bangladesh. Families and species have been arranged following Nowak (1991).

\section{Distribution and status of bats in Bangladesh}

\section{Pteropodidae}

Cynopterus sphinx Vahl, 1797. The Short-nosed Fruit Bat (Bucha-nak Kola Badur) is not uncommon in city limits and large market places with sparingly used food and jute storage facilities. It is widespread in southern, western, and northern districts. It is quite common in the Bangladesh Sundarbans. It is also common in Project Tiger areas of the West Bengal parts of the Sundarbans (Mandal \& Nandi, 1989). In Dhaka City I have earlier reported it from the fronds of palmyra palms and tree hollows (Khan, 1985). It hangs down the underside of banana leaves, singly or in pairs, in disused pump-house, dilapidated buildings, and ruins of forts in Dhaka City and all over the country where there is guava, banana, mango and Zizyphus orchards. Often it is late to head for the roost at dawn when it is seen mobbed by crows.

Pteropus giganteus Brünnich, 1782. The Indian Flying Fox, (Badur/ Champa Badur) is the largest of the bats. The flying foxes were widely distributed all over the country and used to be very common in towns, villages and in forested areas twothree decades back. They regularly roosted in large groups of a hundred to over a thousand bats in banyan and fig trees (Ficus benghalensis, F. religiosa), mango (Mangifera indica), rain tree (Enterolobium saman), albizia trees (Albizia lebbeck, A. procera, A. richardiana), Manila tamarind (Pithecellobium dulce), Alstonia scholaris, Syzygium spp., Cassia fistula, C. siamea, Casuarina equisetifolia, Bombax ceiba, Dalbergia sissoo, Erythrina ovalifolia, Polyalthia longifolia, Trewia polycarpa, Terminalia bellerica, coconut (Cocos nucifera), palmyra palm, and bamboo clumps (Dendrocalamus strictus, Bambusa arundinacea). Same roosting trees were used year after year. However, from 1970 onwards there started wholesale removal of softwood trees for curing tobacco leaves and for brick burning in thousands of brickfields across the country. Banyan, Asltonia, Trewia, Bombax, etc., used to grow abundantly in the high grounds, along highways, countryside bullock cart tracks and fallow lands, all along bridal paths through the villages, in countryside market places, seats of worships - especially in spots where Hindus used to have their idols placed seasonally, compounds of police stations and government rest houses. All these trees were either purchased from the villagers at a very cheap rate or were just removed through unfair means by brickfield and tobacco related business people. These were also used as firewood for boiling tar for covering the top of all the highways and metalled roads. Now there are literally no tall trees in village groves excepting coconut and palmyra palms. So, most large colonies of flying fox have disappeared. It is estimated that at least 80 per cent of the roosting trees of the flying fox has been lost in the process.

However, certain places of worship, such as a few old Hindu temples, pagodas of Buddhists, and graveyards in remote corners of the country still support a few fig/banyan trees and in turn these provide roosting places for the last remaining large colonies of bats. Also, the flying foxes have started using alternative roosting trees, for example, exotic Albizia richardiana, Casuarina equisetifolia, Enterolobium saman, Eucalyptus globosus, Trema orientalis, etc. Never-the-less, only a few dozens of these bats can roost in such trees against hundreds roosting in fig/banyan trees. At present large number of flying foxes are sighted all along the Sundarbans and areas bordering it.

In the past a major natural diet for the flying foxes included wild banana (commercially unimportant species of banana used to be grown in the villages more for shed, as soil binder and as fodder than as fruit-bearing plant), fruits of all Ficus spp., nectar and flowers of silk cotton, Anthocephalus kadamba, Polyalthia longifolia, exotic eucalyptus, indigenous guava, mango, litchi, sapota, custard apple, tamarind, etc. Now, these are rare commodities for the bats. However, Anthocephalus and Polyalthia fruits are still available in appreciable numbers but these fruits are very seasonal. So, flying foxes are largely dependent on cultivated fruits. During the litchi-growing season, orchard owners try to protect their fruits by covering the entire fruiting trees with fine-mesh fishing nets. They use empty tins of kerosene as drums for producing sound as a means to scare away the bats, keep all night vigil over the orchard and drive away the bats by shouting or shooting guns in the air. Owners of mango orchards also follow the same practise. However, guava and banana cultivators are at a loss as their gardens are too large to be protected from bats through the above methods. 
Habitat loss and alteration of habitats have forced the flying foxes to live in small colonies of a few individuals to several dozen bats in a roosting tree. At present large roosts are found only near the Sundarbans forest and a few stray ones in the countryside. Death due to collision with electric cables seems inevitable and will continue to be a threat in the future until the electricity board and the wildlife authorities adopt bat protection measures.

Rousettus leschenaulti (Desmaret, 1820). The Fulvous Fruit Bat/Leschenault's Rousette (Kola Badur) is the second largest species of fruit bat in the country. This species seems to be partial to forests. It is common in the Sundarbans, in the scattered forests of the northern Sal forest at Gazni in Sheerpur District, in the northeastern forests and the semievergreen forest of southeastern Bangladesh. I have so far found the largest colony of this bat in a cave, locally known as Kudum Cave, $3 \mathrm{~km}$ west of Whykeong Forest Office $\left(21^{\circ} 6^{\prime} 88^{\prime \prime} \mathrm{N}\right.$ and $\left.92^{\circ} 11^{\prime} 66^{\prime \prime} \mathrm{E}\right)$ under Cox's Bazar District and Forest Division, in the middle of a denuded semievergreen forest (Khan, 1985). This is also the only bat cave that I have ever known from 1980 to be occurring in the country. I visited it last in 1997. Here about 50 Fulvous Fruit Bats were found along with two other insect bat species numbering 150-200. Fruit bats were found towards the front section, while others were much deep inside the $10 \mathrm{~m}$-long and $2 \mathrm{~m}$-wide cave. This bat is usually seen singly around banana, guava and cashew nut garden around the tribal Chakma villages in the southeastern forest, often found along stream banks that support luxuriant growth of Ficus glomeratus, F. hispida, and F. racemosa. It eats fleshy fruits of Artocarpus lakoocha, Gmelina aborea, Mimusops elengi and flowers of Duabhanga grandiflora, Bombax ceiba, Mesua ferrea, Mangifera longipes, Swintonia floribunda in semievergreen forests. The bat also visits Sonneratia, Avicennia, Nypa Palm, Phoenix paludosa and Pandanus odoratissimus blooms in the Sundarbans.

\section{Emballonuridae}

Taphozous longimanus Hardwicke, 1825. Long-winged Tomb Bat (Tholeyjukta Chamchika). It is widely distributed in the country and is a common species. It is always associated with coconut and other palms, old tombs, monuments and crevices in buildings as well as in tree hollows. Ahmed and Hussain (1982) report that the species is not seen in Bangladesh.

Taphozous melanopogon Temminck, 1841. Black-bearded Tomb Bat (Darijukta). It is also a common bat and found almost all over the country. It prefers old buildings, cracks and crevices in buildings, and in hollows in dead trees, especially dying ficus trees. This species is not reported from Bangladesh by Bates and Harrison (1997).

Taphozous saccolaimus Temminck, 1838. Pouch-bearing Bat (Jhalor-leji Chamchika). Possibly the most common of the sheath-tailed bats. Distributed all over the country, it prefers old buildings and hollows in trees.

\section{Hipposideridae}

Coelops frithii Blyth, 1848. Tail-less Leaf-nosed Bat (Lejhin Patanak Chamchika). It is not uncommon in the Sundarbans and lives under split tree barks and clefts in small groups of half a dozen animals.

Hipposideros galeritus Cantor, 1846. Cantor's Leaf-nosed Bat, (Cantorer Patanak Chamchika). It is widely distributed and the most common among the leaf-nosed bats. This bat roosts in tombs, old buildings and in caves. Usually noted in colonies ranging from a dozen to several dozens. Bates and Harrison (1997) have not reported this species from Bangladesh.

Hipposideros lankadiva Kelaart, 1850. Kelaart's Leaf-nosed Bat (Guhabashi Patanak Chamchika). It lives in the Sundarbans and adjacent areas. Bates and Harrison (1997) do not report this species from Bangladesh, therefore this is a new report for Bangladesh. Earlier, Mandal and Nandi (1989) have reported it from the West Bengal part of the Sundarbans. It lives in crevices in trees, in Nypa palm fronds and in abandoned forest lodges.

Hipposideros larvatus (Horsfield, 1823). Horsfield's Leafnosed Bat (Majhari Patanak Chamchika). Uncommon and mostly confined to the northeastern and southeastern hill country.

\section{Megadermatidae}

Megaderma lyra E. Geoffroy, 1810. Greater False Vampire (Daini Badur). It is the most common among the insect bats and is found all over the country. It is common equally in city limits and in forests. This is the only large insect bat that comes out of its hiding at sun down. This observation is contrary to the one made by Sinha (1986) who reported it to be coming out of roosts about half an hour after sunset in Bihar, India. Its large size and quite swift flight separates it from the rest of the insect bats. False Vampire prefers to live in abandoned buildings or human dwellings, tombs, cracks and crevices in buildings as well as in tree hollows. It is known to feed on rats, mice, house shrew, other bats and small birds like the palm and house swifts, in addition to insects and moths in Bangladesh. Sinha (1986) has reported it to be eating house shrew, Hipposideros and Rhinopoma bats, rats and birds.

Megaderma spasma Linnaeus, 1758. Lesser False Vampire (Chhoto Daini Badur). It is more common in the Sundarbans and other frosted areas of the country than the countryside. It is not as aggressive a carnivore as the false vampire is. It feeds chiefly on insects and roosts in crevices and hollows in trees and rocks. This is the first record of the species from the 
country. Mandal and Nandi (1989) has reported it from the West Bengal part of the Sundarbans. Bates and Harrison (1997) have not reported this bat from Bangladesh.

\section{Molossidae}

Tadarida aegyptiaca (E. Geoffroy, 1818). Egyptian Free-tailed Bat (Lomba-leji Chamchika). Rarely found in the forested areas of the country. Roosts under large branches, clefts and hollows in trees. Not reported in Bangladesh by Bates and Harrison (1997).

\section{Rhinolophidae}

Rhinolophus lepidus Blyth, 1844. Blyth's Horseshoe Bat (Chhoto Ghorakhuri Chamchika). It is the smallest of the horseshoe bats occurring in the country. Common and widely distributed in forests and countryside but not found in large numbers. This bat prefers crevices and cracks in disused roads, railway bridges, culverts, wells and dark rooms sparingly used by people. This species is not reported from Bangladesh by Bates and Harrison (1997).

Rhinolophus luctus Temminck, $\mathbf{1 8 3 5}$. Woolly Horseshoe Bat (Woolwala Chamchika). It is likely to be present in the semievergreen forests of the northeastern and southeastern parts of the country. This species is not reported from Bangladesh by Bates and Harrison (1997).

Rhinolophus pearsonii Horsfield, 1851. Pearson's Horseshoe Bat (Pearsoner Ghorakhuri Chamchika). This is rare and partial to forests. It is known to roost in trees either in dark forks or in clefts that do not get any sunlight. This species is not reported from Bangladesh by Bates and Harrison (1997).

Rhinolophus subbadius Blyth, 1844. Little Nepalese Horseshoe Bat (Sadharan Ghorakhuri Chamchika). This is common among the horseshoe bats in the low hills of northern and northeastern parts of the country and adjacent areas. It prefers Sal forests and in Sylhet-Moulvi Bazar districts it is found in Dipterocarp-Lagerstroemia forests. It lives in hollows, furrows and cracks in trees. This species is not reported from Bangladesh by Bates and Harrison (1997).

\section{Rhinopomatidae}

Rhinopoma hardwickii Gray, 1831. Lesser Mouse-tailed Bat (Chhoto Indur-lenji Badur). This bat is relatively rare in the country. It is partial to southwestern parts and not uncommon around the Sundarbans. It lives in crevices and cracks in trees, and occasionally in abandoned human dwellings. This species is not reported from Bangladesh by Bates and Harrison (1997).

Rhinopoma microphyllum (Brünnich, 1782). Greater Mousetailed Bat (Indur-lenji Chamchika). Widely distributed in the hilly areas of northern, eastern and southeastern parts of the country but not a commonly observed species. Old pagodas, Buddhist and Hindu temples, monuments in Hindu cremation sites, rock crevices and hollows of old banyan/fig trees are preferred roosting sites where up to half-a-dozen animals can be found. This species is not reported from Bangladesh by Bates and Harrison (1997).

\section{Vespertilionidae}

Eptesicus pachyotis (Dobson, 1871). Thick-eared Bat (Motakanwala Chamchika). Occurs patchily in northeastern hilly and forested areas of the country. It roosts in tree hollows and clefts. Not listed in Bangladesh by Bates and Harrison (1997).

Kerivoula papillosa Temminck, 1840. Papillose Bat (Jhalarjukta Rongila Chamchika). More common in semievergreen forest than the Sundarbans. Very few in sal forest. Roosts amongst foliage or palm fronds. Not reported in Bangladesh by Bates and Harrison (1997).

Kerivoula picta (Pallas, 1767). Painted Bat (Komola-badami Chamchika). Fairly common in all forests. Often flies with very slow wing-beats, more like a butterfly through the low foliage in the forest. Roosts amongst dry leaves of tree ferns, dry vines and wild palms and bananas either singly or in twos.

Myotis formosus (Hodgson, 1835). Hodgson's Bat (Hodgsoner Chamchika) is an uncommon species found in the northeastern parts of the country, mostly in well-wooded areas of the countryside and in forests. Bates and Harrison (1997) have not reported this species.

Pipistrellus ceylonicus (Kelaart, 1852). Kelaarts' Pipistrelle (Kelaarter Chamchika). It is an uncommon but widely distributed species in the country. Usually seen singly or in small groups of 3-4 individuals in abandoned houses, crevices in railway bridges and culverts; also rarely in hollows in old tree trunks. Occasionally large colonies are seen in old and dilapidated monuments and tombs.

Pipitrellus coromandra (Gray, 1838). Indian Pipistrelle, Coromandel Pipistrelle, Little Indian Bat (Khudey Chamchika). Possibly the most common bat in the country. Its preferred haunts are human dwellings in tin-sheds, wood houses or thatched houses, especially in rafters, ceilings, and beams. Not uncommon in cattle sheds, outhouses or countryside latrines. However, it lives in dark areas, holes in bamboo and wooden poles, crevices and cracks in buildings. It is usually found in small numbers (often only two animals), less than a dozen animals in an area.

Pipistrellus dormeri (Dobson, 1875). Dormer's Bat (Dormerer Chamchika). It is rarely found in old parts of cities and towns 
with many old buildings, railway station and Steamer Ghats in western and northern parts of the country, e.g. in Rajshahi and Dinajpur. This species is confined to India and Pakistan according to Bates and Harrison (1997).

Pipistrellus savii (Bonaparte, 1837). Savi's Pipistrelle (Savir Chamchika). This is the most uncommon of all pipistrelles and rarely encountered in Bangladesh. Partial to northeastern forests and old sections of towns and ruins. Bates and Harrison (1997) have not reported this species from Bangladesh.

Pipistrellus tenuis (Temminck, 1840). Indian Pygmy Bat, Least Pipistrelle (Chamchika). It is less common and widely distributed than $P$. coromandra and is seen more often in southwestern parts of the country. It lives in small colonies of a few individuals or in pairs in each roost.

Scotophilus heathii Horsfield, 1831. Asiatic Greater Yellow House Bat (Bora Rongila Chamchika). It is less common than S. kuhlii but distributed widely in the country. Often partial to large old trees, palmyra palm, dilapidated buildings, forts, monuments, tombs, etc. Roosts in small numbers.

Scotophilus kuhlii Leach, 1821. Asiatic Lesser Yellow House Bat (Chhoto Holdey Chamchika). It is usually found in the southern part of the country, including St. Martin's Coral Island and the Sundarbans (Khan, 1982). I found a roost in a tin-shed of a forest office at Jahazmara Ghat in Hatia Island in January 1995. Roosts in twos or dozens huddled together under ceilings in sparingly used houses, in attics, in tall palm trees, and in fig/ banyan tree furrows.

Scotomanes ornatus (Blyth, 1851). Harlequin Bat (Rongila Chamchika). Partial to northeastern forests, not common. Occasionally visits banana plantations. Not listed in Bangladesh by Bates and Harrison (1997).

\section{Discussion}

This paper is a preliminary report on 31 species of bats, belonging to nine families from Bangladesh. It includes records of three species that have not been reported earlier from Bangladesh. One is a false vampire and two others are leaf-nosed bats. Bats play such a vital role in controlling insect pests of agricultural crops, fruit orchards, pollination of flowers of forest trees and dispersal of seeds that there is an urgent need for a thorough survey of Bangladesh for the determination of taxonomic status of the species occurring in the country. Also collection of specimens could reveal the presence of a few more species that are present in the neighbouring areas of West Bengal, Tripura, Assam and Mizoram of India. It is very important to determine how much damage is done to the cash fruits such as banana, litchi and mango by the fruit bats.
Excessive exploitation of natural resources, alteration of habitats and cutting down of tall trees have depleted the bat populations in Bangladesh. Most hard hit species is the flying fox that is finding it difficult to get tall trees for roosting. Urgent measures are needed to save the bats from fast decline in Bangladesh. Last remaining roosting trees of the Flying Fox needs to be saved from cutting by declaring these as national property.

The third schedule of the Bangladesh Wildlife Preservation Act 1973 provides blanket protection to most of the major vertebrate classes with the exception of 'poisonous snakes, rats, mouse, fruit bats, pipistrelles, etc., which endanger public life. This Act needs to be amended to provide ample protection to the bats.

There is an urgent need for making the public aware about the beneficial aspects of all the bats and removing the century-old misconceptions about bats.

\section{Acknowledgement}

I am thankful to Professor A.K. Nazrul Islam, Department of Botany, Dhaka University, Bangladesh for giving me information on the top-dying of Sundri trees in Bangladesh Sundarbans.

\section{References}

Ahmed, S.K. (1975). Bats of Bangladesh (with notes on field observation). M.Sc. Thesis (unpublished). Dhaka University, Bangladesh.

Ahmed, S.K. and K.Z. Husain (1982). Bats of Bangladesh. Journal of the Asiatic Society of Bangladesh (Science) 8: 89-99.

Bates, P.J.J. and D.L. Harrison. (1997). Bats of the Indian subcontinent. Harrison Zoological Museum, xvi+258 pp. with 8 plates.

IUCN Bangladesh (2000). Red Book of Threatened Mammals of Bangladesh. Dhaka: IUCN Country Office, Bangladesh, xii+71 pp. Khan, M.A.R. (1982). Wildlife of Bangladesh - a Checklist. Dhaka University, Dhaka, iv+174 Pp.

Khan, M.A.R. (1985). Mammals of Bangladesh. Nazma Reza, Dhaka, iv+92 Pp.

Khan, M.A.R. (1987). Bangladesher Bonnyaprani (in Bengali). Dhaka Bangla Academy, x+136 pp. Reprinted with revision in 1996.

Khan, M.A.R. (In Press). Checklist of the Wildlife of Bangladesh. ca. 200 pp.

Mandal, A.K. and N.C. Nandi (1989). Fauna of Sundarban Mangrove Ecosystem, West Bengal, India. Zoological Survey of India, Calcutta, vi+116 pp with 15 plates.

Nowak, R.M. (1991). Walker's Mammals of the World. Vol.1, $5^{\text {th }}$ Edition. The John Hopkins University Press, Baltimore and London, xiii+ 642 pp.

Sarker, S.U. and N.J. Sarker (1988). Wildlife of Bangladesh - A Systematic List. The Rico Printers, Dhaka, xix +59 pp.

Sinha, Y.P. (1986). Records of the Zoological Survey of India: Occsional Paper No. 77. Zoological Survey of India, Calcutta, iii+60 pp with 6 plates. 